\title{
The Impact of Industrial Policy on Capital Structure with Financial \\ Flexibility, Macroeconomic Conditions and Economic Growth and Development Taken into Account: Evidence from Taiwan
}

\author{
Hsien-Hung Yeh* \\ National Pingtung University of Science and Technology, \\ Taiwan \\ and \\ Griffith Business School, Griffith University, \\ Australia \\ *Correspondent author
}

and

\section{Eduardo Roca}

Griffith Business School, Griffith University, Australia

\begin{abstract}
This paper examines the impact of industrial policy on capital structure based on a partial adjustment model of capital structure that incorporates financial flexibility, macroeconomic conditions, economic development as well as firm-level factors. The issue is investigated in the context of Taiwan where industrial policy is widely considered to have played a strategic role in its economic success. The results show the significance of financial flexibility, macroeconomic conditions, economic growth and development, industry effect, as well as firm-level factors in the determination of capital structure change in the plastics and textile industries in Taiwan. However, the findings reveal no significant impact of government industrial policy on capital structure changes.
\end{abstract}

Keywords: capital structure change; industrial policy; financial flexibility; macroeconomic conditions; economic growth and development; Taiwan.

\section{Introduction}

Most prior studies have given much attention to the determination and determinants of capital structure only at the firm and industry levels after the classic work of Modigliani and Miller (1958). Only few of them, however, addressed the issue with macroeconomic conditions (Ferri and Jones, 1979; Yeh, 2002; Korajczyk and Levy, 2003; Hackbarth et al., 2006; Yeh and Roca, 2007b) and economic growth and development (Boyd and Smith, 1996; Chen, 2004; Yeh and Roca, 2007a) taken into account. Besides, the evidence of economic impact on capital structure is mixed among these few studies. Further, financial flexibility is conceptually recognized as an important factor of capital structure decisions (Myers and 
Majluf, 1984; Narayanan, 1988) but it has been neglected by prior studies except by some surveys (Pinegar and Wilbricht, 1989; Allen, 1991; Graham and Harvey, 2001) and recent Taiwanian studies by Yeh and Roca (2007a; 2007b). Still further, Appelbaum (1993) analyzes the effect of government intervention such as bailout, subsidies and tax benefits other than corporate and personal taxes on capital structure decisions and concludes that, since government's policies are not priced in the market, firms can maximize the value of government's intervention through their capital structure decisions. However, no studies have empirically examined the impact of government industrial policy on capital structure decisions.

Taiwan has a successful experience of economic transition from an emerging country to a developed one within decades. The textile and plastics industries are important contributors to the economic growth and received strong support from government industrial policy in the different stages of economic development of Taiwan as discussed later in the Literature Review section. Therefore, with data availability under consideration, we conduct this study in the context of the textile and plastics industries during the period of 1981 to 1995 in the course of economic development with different industrial policies in Taiwan, in order to test the effect of government intervention, through industrial policy, on capital structure decisions of firms. Note, however, that the effect of different types of government intervention on capital structure and the efficacy of industrial policy itself are beyond the scope of this paper.

This paper follows the line of the research on capital structure and extends the work of Yeh and Roca (2007a; 2007b). We investigate the significance of government industrial policy in the determination of capital structure with financial flexibility, macroeconomic conditions as well as economic growth and development under consideration. This paper provides a new perspective and evidence in the determination of capital structure choices based on the experience of Taiwan. The rest of this paper is organized as follows. Section 2 presents the literature review. Section 3 describes the partial adjustment model of capital structure. The empirical methodology is discussed in Section 4. The empirical results and analysis are presented in Section 5 and, finally, Section 6 provides the conclusions of the paper.

\section{Literature Review}

After the work of Modigliani and Miller (1958), studies have focused mostly on the determination and determinants of capital structure decisions at the firm and industry levels only. Rarely did prior studies on capital structure address the issue at the macroeconomic level with macroeconomic conditions (Ferri and Jones, 1979; Yeh, 2002; Korajczyk and Levy, 2003; Hackbarth et al., 2006; Yeh and Roca, 2007b) and economic development (Boyd and Smith, 1996; Chen, 2004; Yeh and Roca, 2007a) under consideration. Besides, these few studies have mixed conclusions on the macroeconomic impact on capital structure. Moreover, there is practically no attention given on the impact of government industrial policy on capital structure. We discuss these further in this section.

\subsection{Industrial Policy and Capital Structure}

Appelbaum (1993) analyses the effect of government intervention such as bailout, subsidies and tax benefit other than corporate and personal taxes on the determination of capital structure. Appelbaum argues that, since the government's policies are not priced in the market, firms under government's policies can utilize the choice of capital structure to maximize the value of government's policies and add the value to their firm value. The Taiwanian government implemented different industrial policies for the purpose of achieving 
industrial development as well as economic growth and development since the 1950s (Chu, 2003; Chiang, 2004). During the 1950s, an industrial policy based on import substitution was implemented by the Taiwanian government to promote the development of light manufacturing industries, such as the food and cement industries, in response to high unemployment and other economic problems. Then, during the 1960s and early 1970s, an industrial policy based on export expansion was carried out by the Taiwanian government to encourage light manufacturing industries such as the textile industry to increase exports due to the limited domestic demand. Further, during the period between the early 1970s and the mid-1980s, an industrial policy of import substitution was implemented again by the Taiwanian government to develop the petro-chemical industries, such as plastics industry. During the period between 1986 and the early 1990s, Taiwan carried out economic liberalization and adopted an industrial policy that promotes strategic industries with high market share potential, value addition, industry spillovers and technological intensity as well as those with low energy demand and pollution, such as the electronics, high-tech machinery and bio-technology industries. After the mid-1990s to the present, Taiwan continued to promote the development of high-tech industries and those industries related to the knowledge-based economy. However, no studies have given attention to the impact of industrial policy on capital structure. Therefore, this paper addresses this research gap in the context of the textile and plastics industries in Taiwan.

\subsection{Financial Flexibility and Capital Structure}

To respond to future growth or investment opportunities, firms may reserve borrowing capacity or financial slack in order to maintain financial flexibility. The more the borrowing capacity reserved for maintaining financial flexibility, the smaller the adjustment toward the target capital structure. Myers and Majluf (1984) claimed that shareholders can be better off when the firm reserves financial slack for future financial needs. Narayanan (1988) also claimed that it is better for firms to build up financial reserves of internal funds for future investment opportunities. A few surveys (Pinegar and Wilbricht, 1989; Allen, 1991; Graham and Harvey, 2001) have documented the qualitative evidence on the importance of financial flexibility in determining capital structure. Recently, Yeh and Roca (2007a; 2007b) provide quantitative evidence on the negative impact of financial flexibility on capital structure. Following the work of Yeh and Roca, we include financial flexibility in this study and expect that financial flexibility will have a negative impact on capital structure changes.

\subsection{Macroeconomic Conditions and Capital Structure}

Stulz (1990) contends that, to reduce the cost of overinvestment and underinvestment, firms finance with more debt when cash flow increases but less debt when cash flow decreases. Jensen's free cash flow theory (1986) also asserts that debt can be used to motivate managers and their organizations to be efficient in the case of large free cash flow. In addition, some determinants of capital structure such as growth opportunities, cash flow and profitability also vary with current state of the economy. Further, the probability that firms will have free cash flow increases during the period of expansion but decreases during the period of recession. These imply that there are more future growth opportunities available to firms at economic trough but less growth opportunities available to firms at economic peak. Therefore, capital structure would be pro-cyclical or positively related to macroeconomic conditions due to the negative relationship between capital structure and growth opportunities according to the agency models.

However, when Korajczyk and Levy (2003) test the impact of macroeconomic conditions on capital structure with financial constraints under consideration, they find that corporate 
leverage is negatively related to macroeconomic conditions for the financially unconstrained firms. In addition, when Hackbarth et al. (2006) analyze credit risk and capital structure decisions in their contingency-claims model, they conclude that corporate leverage should be countercyclical. However, Yeh and Roca (2007b) apply the partial adjustment model of capital structure in their recent Taiwanian study and find a significant negative relationship between macroeconomic conditions and capital structure for the years before tax integration but an insignificant positive relationship after tax integration.

Based on the relationship among macroeconomic conditions, firm-level factors and capital structure and, in addition, as suggested by Stulz, we expect that macroeconomic conditions would have a positive impact on capital structure.

\subsection{Economic growth and development and Capital Structure}

Boyd and Smith (1996) contend that more developed economies could lose fewer resources than do less mature economies due to intermediation costs. The evolution of financial market development tends to provide an economy with a more efficient capital market and thus there is practically no use for equity markets at low levels of financial market development. Once the economy reaches a certain level of financial market development, corporate financing via equity markets can be found because of the benefit of financial market development. Boyd and Smith conclude that the ratio of equity financing rises as an economy develops. Therefore, corporate debt ratio will be negatively related to economic development. However, Chen (2004) finds no certain relationship between economic development and debt-equity ratio from the Flow of Funds Account or National Balance Sheet instead of corporate balance sheet among four countries. Chen finds a negative relationship between debt-equity ratio and economic growth in Taiwan during the years 1965 to 2001 but a positive one in the USA during the years 1946 to 2002. In addition, in a recent Taiwanian study, Yeh and Roca (2007a), found an insignificant negative relationship between capital structure changes and economic growth and development for the years of economic trough and peak before and after tax integration of 1998.

\subsection{The Firm-Level Determinants of Capital Structure}

Over the last several decades, much research addressed capital structure choices and found some common firm-level determinants of capital structure such as firm size, growth opportunities, profitability, non-debt tax shields and collateral value of asset structure (Harris and Raviv, 1991). We therefore include these as control variables in order to avoid model misspecification and, in addition, to provide additional evidence on these determinants of capital structure.

\subsection{Interaction Effects on Capital Structure}

As suggested by prior studies (Ferri and Jones, 1979; Yeh, 2002; Yeh and Roca, 2007a; Yeh and Roca, 2007b), the relationship between firm-level determinants and capital structure may be conditioned by macroeconomic conditions. Therefore, this study also investigates the effect of interactions between firm-level factors and macroeconomic conditions for additional evidence on the impact of the cross-level interactions on capital structure changes.

\section{The Partial Adjustment Model of Capital Structure}


Several studies have documented that actual capital structure of firms may deviate away from their target capital structure in the short run (Taggart, 1977; Marsh, 1982; Jalilvand and Harris, 1984) and, in addition, the target capital structure can change over time (Hovakimian et al., 2001). As suggested by related work regarding the concept of financial flexibility (Myers and Majluf, 1984; Narayanan, 1988) and recent empirical studies (Yeh and Roca, 2007a; Yeh and Roca, 2007b), we assume that actual adjustment toward the target capital structure at a given year $t$ is a fraction of the desired adjustment, i.e. the difference between the target capital structure and actual previous capital structure. Moreover, we assume that the adjustment toward the target capital structure is determined by the financial flexibility of firms. The more the demand for financial flexibility, the smaller the capital structure change will be. Note that if financial flexibility does affect the capital structure of firms, then the rate of adjustment speed should be less than one. According to the standard partial adjustment model, the equation for actual adjustment toward the target capital structure with financial flexibility taken into account is written as follows.

$$
Y_{i t}-Y_{i t-1}=\gamma_{t}\left(Y_{i t}^{*}-Y_{i t-1}\right)+\varepsilon_{i t}
$$

where, $Y_{i t}{ }^{*}$ : the target capital structure of firm $i$ at time $t, \mathrm{Y}_{\mathrm{it}}$ : the actual capital structure of firm $i$ at the end of year $t, \mathrm{Y}_{\mathrm{it}-1}$ : the actual capital structure of firm $i$ at the beginning of year $t$, $\gamma$ : the speed of actual adjustment toward the target capital structure that is determined by financial flexibility and $\varepsilon$ : error term. However, target capital structure is unobservable. As suggested by prior studies, this paper assumes that the firms in the sample have the same adjustment speed and the target capital structure is a linear function of the factors at the firm and industry levels, government industrial policy, macroeconomic conditions, economic growth and the stages of economic development as well as the interactions of macroeconomic conditions' with firm-level factors. Consequently, the equation for the target capital structure can be written as follows.

$$
\begin{aligned}
Y_{i t}^{*}= & \sum_{j=1}^{c} \beta_{j i} X_{j i t}^{F C}+\beta^{I N D} I N D_{i t}+\beta^{G I P} G O V I N D_{i t}+\beta^{E C} E C_{i t}+\beta^{E D} E D_{i t}+\beta^{E D P} E D P_{i t} \\
& +\sum_{j=1}^{c} \beta_{j i}^{F C X E C} X_{j i t}^{F C} E C_{i t}
\end{aligned}
$$

where, $Y_{i t}^{*}$ : the target capital structure of firm $i$ at the end of year $t, \beta$ : the regression coefficient, $X$ : the variables at the firm level, IND: the dummy variables for industry types, GOVIND $_{\mathrm{t}}$ : the dummy variable with a value of 1 for the industry with the support from the government industrial policy at year t, EC : the dummy variable for macroeconomic conditions with a value of 0 for recession and 1 for expansion, ED: the variable for economic growth, $\mathrm{EDP}_{\mathrm{t}}$ : the dummy variables for the stages of economic development at year $t$ and $\mathrm{X} \times \mathrm{EC}$ : interactions between firm-level factors and macroeconomic conditions. Substituting $Y_{i t}^{*}$ in Equation 2 into Equation 1 and putting all the individual firm-level variables suggested by prior studies into it, we can derive Equation 3, the partial adjustment model of capital structure as follows.

$$
\begin{aligned}
Y_{i t}-Y_{i t-1}= & \gamma \beta_{1} \text { SIZE }+\gamma \beta_{2} \text { GROWTH }+\gamma \beta_{3} \text { PROFIT }+\gamma \beta_{4} \text { NDTS }+\gamma \beta_{5} \text { ASSET } \\
& +\gamma \beta^{I N D} I N D_{i t}+\gamma \beta^{G I P} G O V I N D_{i t}+\gamma \beta^{E C} E C_{i t}+\gamma \beta^{E D} E D_{i t}+\gamma \beta^{E D P} E D P_{i t} \\
& +\gamma \beta_{6} \text { SIZE } \times \text { EC }+\gamma \beta_{7} \text { GROWTH } \times \text { EC }+\gamma \beta_{8} \text { PROFIT } \times \text { EC } \\
& +\gamma \beta_{9} \text { NDTS } \times \text { EC }+\gamma \beta_{10} \text { ASSET } \times \text { EC }-\gamma Y_{i t-1}+\varepsilon_{i t}
\end{aligned}
$$


where, $Y_{i t}-Y_{i t-1}$ : capital structure change, $\beta$ : regression coefficient, $\gamma$. adjustment speed, SIZE: firm size, GROWTH: growth opportunities, PROFIT: profitability, NDTS: non-debt tax shields, ASSET : asset structure, IND: the dummy variables for industry types, GOVIND $\mathrm{t}_{\mathrm{t}}$ : the binary dummy variable with a value of 1 for the industry with the support from the government industrial policy at year t, EC : the dummy variable for macroeconomic conditions with a value of 0 for recession and 1 for expansion, ED: the variable for economic growth, EDP: the dummy variables for the stages of economic development, SIZE $\times \mathrm{EC}$, GROWTH $\times$ EC, PROFIT $\times$ EC, NDTS $\times$ EC and ASSET $\times$ EC: interactions between firm-level factors and macroeconomic conditions, $\mathrm{Y}_{\mathrm{it}-1}$ : the previous total debt ratio at the beginning of year $\mathrm{t}$ and $\varepsilon$ : error term.

\section{Empirical Methodology}

\subsection{Research Period and Sample}

We collect annual financial data of the listed firms from the financial data bank of Taiwan Economic Journal. Controlling for the impact of Asian Financial Crisis in 1997 and the tax integration of Taiwan in 1998 and, in addition, considering the availability of financial data, we investigate the impact of industrial policy on capital structure changes during the period of economic growth and development in Taiwan corresponding to the years between 1981 and 1995. In addition, we select the years at economic peak and trough to represent the years of economic expansion and recession, respectively, according to the reference dates in the Business Indicators published by the Council for Economic Planning and Development of Executive Yuan of Taiwan. The years 1983, 1988 and 1994 closest to the reference dates of peak and the years 1985, 1990 and 1995 closest to the reference dates of trough therefore are selected to represent the years of economic peak and trough in the course of economic development in Taiwan, respectively. The sample includes all the firms in the plastics and textile industries that are listed in the Taiwan Stock Exchange and that have sufficient and complete annual data during the sample period. Moreover, based on the changes in the annual growth rate of real gross domestic product, we split the research period ranging from 1983 to 1995 into two stages of economic growth and development, i.e. upward growth period of 1983 to 1987 and downward growth period of 1988 to 1995 in Taiwan.

\subsection{Empirical Model}

In order to investigate the impact of industrial policy on capital structure changes, this study addresses the issue in the context of the textile and plastics industries over two stages of economic growth and development with different industrial policies in Taiwan. We put the proxy variables at firm, industry and economic levels into Equation 3 to get the empirical regression model, i.e. Equation 4 for the determination of capital structure change written as follows.

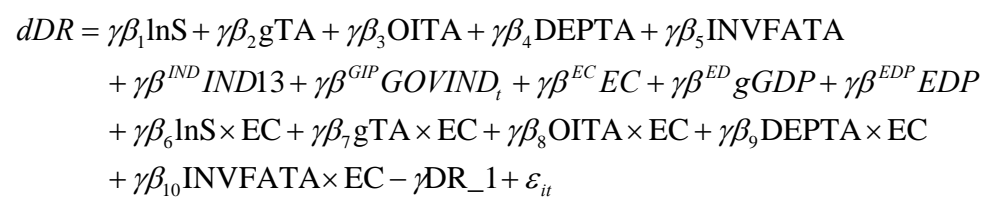

where, $\mathrm{dDR}$ : the change or adjustment in total debt ratios, $\beta$ : regression coefficient, $\gamma:$ the adjustment speed, $\ln \mathrm{S}$ : natural logarithm of net sales, gTA: the annual growth rate of total 
assets, OITA: net operating income/total assets, DEPTA: the ratio of total depreciation to total assets, INVFATA: the ratio of inventory plus net fixed assets to total assets, IND13: the dummy variable with a value of 1 for the plastics industry and 0 for the textile industry, GOVIND $_{\mathrm{t}}$ : the dummy with a value of 1 for the industry with the support by the industrial policy at year t, EC: the binary dummy for macroeconomic conditions with a value of 0 for economic trough and 1 for economic peak, gGDP: the annual growth rate of real gross domestic product, EDP: the dummy variable with a value of 0 for the years between 1983 and 1987 and 1 for the years between 1988 and 1995, $\ln S \times \mathrm{EC}$, gTA $\times \mathrm{EC}$, OITA $\times \mathrm{EC}, \mathrm{DEPTA} \times \mathrm{EC}$ and INVFATA $\times$ EC: the interactions between firm-level factors and macroeconomic conditions, DR_1: total debt ratio of previous year and $\varepsilon$ : error term. Besides, the dependent variable and the explanatory variables except the dummy variables are calculated at book value of annual financial data.

\section{Empirical Results and Analysis}

\subsection{Data Analysis}

The sample includes 340 observations of the listed firms in the textile and plastics industries for the selected years of 1983, 1985, 1988, 1990, 1994 and 1995 in the course of economic growth and development in Taiwan. The debt ratios of the sample firms are less than 0.88, which indicates no financial distress found in the sample firms. The descriptive statistics for the sample are shown in Table 1. Due to high correlation between some explanatory variables, we apply the centering technique suggested by Cronbach (1987) to avoid multicollinearity problem.

Table 1 Summary of descriptive statistics

\begin{tabular}{|l|l|l|l|l|}
\hline Variable & Mean & Standard Error & Minimum & Maximum \\
\hline dDR & -0.01888 & 0.09063 & -0.46459 & 0.32244 \\
\hline lnS & 21.58933 & 1.16808 & 17.99150 & 25.23950 \\
\hline gTA & 0.15447 & 0.28592 & -0.30866 & 2.33787 \\
\hline OITA & 0.06380 & 0.07193 & -0.08115 & 0.59860 \\
\hline DEPTA & 0.04263 & 0.02131 & 0 & 0.12322 \\
\hline INVFATA & 0.62352 & 0.14923 & 0.17021 & 0.89525 \\
\hline DR_1 & 0.46179 & 0.18623 & 0.08955 & 0.89139 \\
\hline IND13 & 0.26765 & 0.44339 & 0 & 1 \\
\hline GOVIND & 0.05000 & 0.21827 & 0 & 1 \\
\hline EC & 0.50588 & 0.50070 & 0 & 1 \\
\hline gGDP & 0.06616 & 0.01082 & 0.04953 & 0.08447 \\
\hline EDP & 0.82059 & 0.38426 & 0 & 1 \\
\hline
\end{tabular}

Notes:

1. Sample size $=340$.

2. $\mathrm{dDR}=\mathrm{DR}_{\mathrm{t}}-\mathrm{DR}_{\mathrm{t}-1}$ and $\mathrm{DR}=$ total debts/total assets; $\operatorname{lnS}=$ natural logarithm of net sales; gTA = annual growth rate of total assets; OITA = net operating income/total assets;

DEPTA = depreciation/total assets; INVFATA = inventory plus net fixed assets/total assets;

DR_1 = total debt ratios of previous year; IND13: dummy variable with 1 for the plastics industry and 0 for the textile industry; GOVIND = binary dummy, 1 for the industry with support by industrial policy;

$\mathrm{EC}=0$ for economic recession and 1 for economic expansion;

gGDP= annual growth rate of real gross domestic product;

$\mathrm{EDP}=$ binary dummy for different stages of economic growth and development, 0 for the years between 1983 and 1987 and 1 for the years between 1988 and 1995.

\subsection{Regression Results}


The regression results are shown in Table 2. No residual autocorrelation and heteroscedasticity as well as multicollinearity problem are found according to the values of Durbin-Watson D, Chi-square and variance inflation shown in the table. In addition, the INFLUENCE option in the SAS regression procedure is used to assess the outlier effect and no observations with values of DFFITS (Belsey et al., 1980) exceeding one are found. We discuss the results further as follows.

\subsubsection{The impact of financial flexibility on capital structure}

Previous total debt ratios (DR_1) are statistically significant and negatively related to capital structure changes. As shown in Table 2, the speed of adjustment toward the target capital structure is significantly different from zero and is about $22 \%$. This implies that financial flexibility has a negative impact on capital structure changes for the listed firms in the plastics and textile industries during the period between 1983 and 1995 in the course of economic development in Taiwan. The finding is consistent with Stulz (1990). The adjustment speed is equal to 0.21999 or 22 percent of the difference between the target debt ratio and the debt ratio of previous year.

Table 2 Regression results (Dependent variable: capital structure changes, dDR)

\begin{tabular}{|l|c|c|c|c|c|}
\hline \multicolumn{1}{|c|}{ Variable } & Coefficient & Standard Error & $\mathrm{t}$ Value & $\operatorname{Pr}>|\mathrm{t}|$ & Variance Inflation \\
\hline DR_1 & -0.21999 & 0.02437 & $-9.03^{\mathrm{a}}$ & $<.0001$ & 1.35604 \\
\hline IND13 & 0.01812 & 0.00958 & $1.89^{\mathrm{c}}$ & 0.0595 & 1.34911 \\
\hline GOVIND & 0.00493 & 0.00682 & 0.72 & 0.4702 & 1.12900 \\
\hline EC & 0.01528 & 0.00826 & $1.85^{\mathrm{c}}$ & 0.0651 & 1.12473 \\
\hline gGDP & 0.97257 & 0.38505 & $2.53^{\mathrm{b}}$ & 0.0120 & 1.14300 \\
\hline EDP & -0.05088 & 0.01099 & $-4.63^{\mathrm{a}}$ & $<.0001$ & 1.17842 \\
\hline lnS & 0.00686 & 0.00365 & $1.88^{\mathrm{c}}$ & 0.0614 & 1.19679 \\
\hline gTA & 0.08472 & 0.01496 & $5.66^{\mathrm{a}}$ & $<.0001$ & 1.20299 \\
\hline OITA & -0.42847 & 0.06100 & $-7.02^{\mathrm{a}}$ & $<.0001$ & 1.26577 \\
\hline NDTS & -0.52516 & 0.22235 & $-2.36^{\mathrm{b}}$ & 0.0188 & 1.47586 \\
\hline INVFATA & 0.08912 & 0.03378 & $2.64^{\mathrm{a}}$ & 0.0087 & 1.67135 \\
\hline lnS $\times$ EC & -0.00827 & 0.00726 & -1.14 & 0.2558 & 1.18266 \\
\hline gTA $\times$ EC & 0.00878 & 0.02980 & 0.29 & 0.7685 & 1.19731 \\
\hline OITA $\times$ EC & -0.04044 & 0.11874 & -0.34 & 0.7336 & 1.20447 \\
\hline NDTS $\times$ EC & -0.08393 & 0.43414 & -0.19 & 0.8468 & 1.40959 \\
\hline INVFATA $\times$ EC & 0.15762 & 0.06067 & $2.60^{\mathrm{a}}$ & 0.0098 & 1.34836 \\
\hline
\end{tabular}

Note: $\mathrm{N}$
Adj. R-squared
F value
$13.50^{\mathrm{a}}$
Durbin-Watson D value 1.952
Chi-square value 104.72

2. ${ }^{\mathrm{a}}{ }^{\mathrm{b}}{ }^{\mathrm{and}}{ }^{\mathrm{c}}$ indicate the significance level of $1 \%, 5 \%$ and $10 \%$, respectively.

\subsubsection{Industry effect and the impact of industrial policy on capital structure}

The dummy IND13 for the plastics industry is statistically significant and positively related to capital structure changes over two stages of economic growth and development with different industrial policy in Taiwan. This shows the significance of the industry effect in capital structure changes and indicates that capital structure changes of the firms in the plastics are greater than those in the textile industry. However, the results show no significant impact of industrial policy (GOVIND) on capital structure changes. This implies no significant effectiveness of government industrial policy in capital structure changes of the listed firms in the textile and plastics industries between 1983 and 1995 over the stages of economic growth and development in Taiwan, which is not consistent with Appelbaum (1993). 


\subsubsection{The economic impact on capital structure}

As expected, the results show that macroeconomic conditions have a positive effect on capital structure changes over the stages of economic growth and development with different industrial policy. The finding is consistent with Stulz's conclusion. Further, the results also show a positive impact of economic growth on capital structure changes over two stages of economic growth and development. In addition, the dummy EDP has a significantly negative effect on capital structure changes, which indicates that capital structure changes during the years between 1983 and 1987 are greater than those during the years between 1988 and 1995. The finding of the long-term impact of economic development on capital structure changes is consistent with the conclusion of Boyd and Smith (1996).

\subsubsection{The effect of firm-level factors on capital structure}

Similar to the finding in prior studies, firm-level determinants of capital structure such as firm size, growth opportunities, profitability, non-debt tax shields and collateral value of asset structure are found in this study.

\subsubsection{Interaction effect on capital structure}

The results show that there is a significant impact of interaction between macroeconomic conditions and a firm-level factor, i.e. collateral value of asset structure, over two stages of economic growth and development in Taiwan. This indicates that, as expected, the effect of asset structure on capital structure changes is augmented by macroeconomic conditions.

\section{Conclusions}

We find that industrial policy has no significant positive impact on capital structure changes for the listed firms in the plastics and textile industries between 1983 and 1995 over two stages of economic growth and development in Taiwan. As expected, we find a negative impact of financial flexibility on total debt ratio changes. Again as expected, macroeconomic conditions have a positive impact on capital structure changes. The results show that economic growth has a positive impact on capital structure changes. Besides, economic development has a negative long-term economic impact on capital structure changes, which is consistent with the conclusion of Boyd and Smith (1996). Finally, we find significant effect of interaction between macroeconomic conditions and firm-level factors on capital structure changes.

\section{Acknowledgements}

The authors are grateful for the helpful comments and valuable suggestions of Dr. Moazzem Hossain and Professor O. Yul Kwon of Griffith University as well as the other participants at the $5^{\text {th }}$ World Association for Sustainable Development International Conference in Nathan Campus of Griffith University, Brisbane, Australia on October 29-31, 2007. 


\section{Reference}

Allen, D. E. (1991) The Determinants of the Capital Structure of Listed Australian Companies: The Financial Manager's Perspective, Australian Journal of Management, Vol. 16, 103-127.

Appelbaum, E. (1993) Government policy and the firm's capital structure, European Economic Review, Vol. 37, 1185-1196.

Belsey, D. A., Kuh, E. and Welsch, R. E. (1980) Regression Diagnostics: Identifying Influential Data and Sources of Collinearity, John Wiley and Sons, New York.

Boyd, J. and Smith, B. (1996) The Co-Evolution of the Real and Financial Sectors in the Growth Process, Federal Reserve Bank of Minneapolis (Working Paper 541).

Chen, L. (2004) The Effects of Economic Development on Corporate Financial Structure, Doctoral Thesis, University of Hawaii.

Chiang, P. K. (2004) Deliberation and Outlook for the Economic Development of Taiwan, Taipei, Taiwan: Linking.

Chu, W. W. (2003) The Economy of Taiwan under Globalization, Taipei, Taiwan: Taiwanese Social Studies.

Cronbach, L. (1987) Statistical Tests for Moderator Variables: Flaws in Analysis Recently Proposed, Psychological Bulletin, Vol. 102, 414-417.

Ferri, M. G. and Jones, W. H. (1979) Determinants of Financial Structure: A New Methodological Approach, Journal of Finance, Vol. 34, 631-644.

Graham, J. R. and Harvey, C. R. (2001) The Theory and Practice of Corporate Finance: Evidence from the Field, Journal of Financial Economics, Vol. 60, 187-243.

Hackbarth, D., Miao, J. and Morellec, E. (2006) Capital structure, credit risk, and macroeconomic conditions, Journal of Financial Economics, Vol. 82, 519-550.

Harris, M. and Raviv, A. (1991) The Theory of Capital Structure, Journal of Finance, Vol. 46, 297-355.

Hovakimian, A., Opler, T. and Titman, S. (2001) The Debt-Equity Choice, Journal of Financial and Quantitative Analysis, Vol. 36, 1-24.

Jalilvand, A. and Harris, R. S. (1984) Corporate Behavior in Adjusting to Capital Structure and Dividend Targets: An Econometric Study, Journal of Finance, Vol. 39, 127-145.

Jensen, M. C. (1986) Agency Costs of Free Cash Flow, Corporate Finance, and Takeovers, American Economic Review, Vol. 76, 323-329.

Korajczyk, R. A. and Levy, A. (2003) Capital structure choice: macroeconomic conditions and financial constraints, Journal of Financial Economics, Vol. 68, 75-109.

Marsh, P. (1982) The Choice Between Equity and Debt: An Empirical Study, Journal of Finance, Vol. 37, 121-144.

Modigliani, F. and Miller, M. H. (1958) The Cost of Capital, Corporation Finance and the Theory of Investment, American Economic Review, Vol. 48, 261-297.

Myers, S. C. and Majluf, N. S. (1984) Corporate Financing and Investment Decisions When Firms Have Information That Investors Do Not Have, Journal of Financial Economics, Vol. 13, 187-221.

Narayanan, M. P. (1988) Debt Versus Equity under Asymmetric Information, Journal of Financial and Quantitative Analysis, Vol. 23, 39-51.

Pinegar, J. M. and Wilbricht, L. (1989) What Managers Think of Capital Structure Theory: A Survey, Financial Management, Vol. 18, 82-91.

Stulz, R. M. (1990) Managerial Discretion and Optimal Financing Policies, Journal of Financial Economics, Vol. 26, 3-27.

Taggart, R. A., Jr. (1977) A Model of Corporate Financing Decisions, Journal of Finance, Vol. 32, 1467-1484.

Yeh, H. H. (2002) The Impact of Economic Fluctuations on Corporate Debt Financing: Empirical Evidence from the Listed Companies in Taiwan, Bulletin of National 
Pingtung University of Science and Technology, Vol. 11, 229-237.

Yeh, H. H. and Roca, E. (2007a) The Impact of Economic Development on Capital Structure Taking into Account Financial Flexibility, Macroeconomic Conditions and Tax Integration: Evidence from Taiwan, The 15th Pacific Basin Finance, Economics, Accounting and Management Conference, Ho Chi Minh City, Vietnam.

Yeh, H. H. and Roca, E. (2007b) The Impact of Financial Flexibility and Macroeconomic Conditions on Capital Structure before and after Tax Integration: Evidence from the Electronic Industries of Taiwan, The 2007 Accounting and Finance Association of Australia and New Zealand Conference, Gold Coast, Australia. 